\title{
Teaching Archaeoastronomy Skills for Roles in the Heritage Sector
}

\author{
Susan Greaney \\ English Heritage \\ susan.greaney@english-heritage.org.uk
}

Should archaeoastronomy be taught as part of an archaeology degree? When asked to contribute to this forum, I was reluctant to do so. As a part-time $\mathrm{PhD}$ student without a paid role in a university department and it being nearly 20 years since I was myself taught at undergraduate level, I felt vastly underqualified to answer this question. To do so would need detailed insight into the varying and competing demands for subjects, knowledge and skills that need to be taught at undergraduate and master's level, not to mention the specifics of the department and university in question, and the existing knowledge of the teaching staff. However, having been invited because my perspective as a heritage professional would be welcome, I can only answer the question from my role as an archaeologist within the heritage sector. So, I must approach the question from the opposite perspective - is knowledge of archaeoastronomy important for careers and professions in heritage? Archaeologists perform a huge variety of roles within heritage organisations, including commercial field archaeology, museums, local authorities, national advisory bodies and tourism sites. Our expertise is relied upon to excavate, record, conserve and interpret archaeological information and resources, and to present these to the public. Part of that interpretation and communication can sometimes involve matters of an archaeoastronomical nature.

For my role, as the only prehistorian (and part-time at that) at English Heritage, some knowledge of archaeoastronomy is important. This is because we look after and care for prehistoric sites that have clear astronomical alignments. At Stonehenge, the stone circles were built to align with both the midsummer sunrise and midwinter sunset, and other alignments or orientations to the Sun and Moon are possible (Chadburn and Ruggles 2017). Conveying this information to visitors relies on models, films, plans, reconstruction drawings and physical markers on site, for which some knowledge of archaeoastronomy is required. Site tours and occasional events such as stargazing evenings also rely on either myself or my colleagues being confident in conveying this information to visitors. Knowledge about the 
solar alignments is also conveyed to the public and learners through the English Heritage website (2020), which includes pages on the summer and winter solstice, as well as our recently launched Stonehenge Skyscape website (Greaney 2020). English Heritage also manages the summer solstice at Stonehenge, and other managed open access events at the equinoxes and winter solstice.

At nearby Woodhenge, another guardianship site, the timber settings were also built to frame the rising Sun at midsummer (Ruggles 2006); this is explained on an interpretation panel at the site and on our website. Other sites that we look after, such as Castlerigg Stone Circle in Cumbria (Higginbottom and Clay 2015), or The Hurlers in Cornwall (Thom 1967, 120; Nowakowski et al. 2020) have been claimed to have astronomical alignments. When producing information for visitors it is important to be able to assess these claims in detail, to decide whether they are worthy of inclusion in the visitor interpretation. As with all aspects of archaeology and history, my role is to weigh up the evidence from numerous sources and sometimes commission new research to present a balanced, clear and informed view of the past.

Was I taught archaeoastronomy at undergraduate or postgraduate level? No. How did I learn about it? Through reading books and periodicals, attending public lectures and asking experts for their advice, thereby gaining the (relatively small amount of) knowledge needed. This could apply to many aspects of the job. How did I learn about Bayesian modelling of radiocarbon dates? By going on a short course. How did I learn about analytical earthwork survey? Through a Masters' training placement and by shadowing experts. How did I learn how to write a visitor information panel? Through several specialist training courses, continual advice from colleagues and years of experience. Not everything that one needs to know as a heritage professional must be taught at undergraduate level.

How many heritage professionals in the UK, like me, require some knowledge of archaeoastronomy in their daily role? It is difficult to estimate. Those who manage heritage sites with alignments, such as Bryn Celli Ddu on Anglesey or Maeshowe in Orkney, no doubt have requirements similar to those of English Heritage. Those working in development control need to understand the significance of skyscapes in designations such as scheduling and World Heritage Site status. Some people working in museums that present archaeoastronomical themes to the public need to have some understanding and on occasion a site examined during developer-funded archaeology may require astronomical interpretation.

There are many other specialist skills that are needed by those working in the heritage sector. Many roles require specialist knowledge of the planning system, of object conservation for museum collections, or the ability to manage large and complex excavation projects. These skills are not taught at undergraduate level either, although some are taught at master's level and others through professional training courses. From a careers and heritage professional perspective, therefore, I feel that archaeoastronomy is a specialist skill that does not need to be taught in detail at an undergraduate level. Certainly, though, some familiarity would be useful - perhaps a lecture in a wider module on archaeological methods or the subject tackled in the context of modules on Neolithic and Bronze Age Europe, ancient Egypt or Mesoamerican civilisations. 
The skills and knowledge required for students, scholars and researchers undertaking academic research is a different matter. For academic research, it would be valuable to have at least one person in each university department proficient in archaeoastronomy to teach introductory courses and to help with student-led research projects and dissertations where these involve assessment of archaeoastronomical research or the collection of primary astronomical data. This, I would argue, applies as much to anthropology, history and astronomy courses as it does to archaeology.

Where, then, should archaeoastronomy be taught? It could be included as part of certain taught master's courses in topics such as prehistoric, landscape or digital archaeology, but only when the expertise is available or when it can be built within a department. More importantly, I would argue that the right place for teaching archaeoastronomy is through a short course, ideally in person but potentially online. Archaeology in the UK has a strong history of short courses, including those run by universities, such as the Department of Continuing Education at the University of Oxford (2020), which runs a variety of training courses on archaeology and the historic environment, or the University of Sheffield, which runs a three-day training course on zooarchaeology (University of Sheffield 2020). Successful courses on skills for the historic environment are also run by Historic England (2020) and by national bodies such as the Natural History Museum, which runs a short course on quaternary palaeoecology (Natural History Museum 2020).

Archaeoastronomy has relevance for postgraduate students tackling research-led masters' or PhDs and to some heritage professionals, but it also has enormous appeal to interested amateurs and members of the public. A short course that set out the history of the discipline, outlined key resources and case studies and taught the use of software packages such as Stellarium (2020) would be a welcome addition to the suite of short courses currently available, if taught by experienced practitioners and to a high academic standard. Such a course would no doubt draw research students, heritage professionals and interested amateurs from across several different disciplines and backgrounds, making the course an interesting networking opportunity, even perhaps fostering crossdisciplinary studies and collaborations.

\section{References}

Chadburn, A. and C. L. N. Ruggles, 2017. "Stonehenge World Heritage Property, United Kingdom". In Heritage Sites of Astronomy and Archaeoastronomy in the Context of the UNESCO World Heritage Convention, edited by C. L. N. Ruggles, 41-62. Thematic Study 2. Bognor Regis and Paris: Ocarina Books and ICOMOS [online]. Accessed August 2020. https://www3.astronomicalheritage.net/_downloads/ocarinabooks. com/heritage-of-astronomy_thematic-study_2ndedition.pdf

English Heritage, 2020. "Solstice" [online]. Accessed July 2020. https://www.english-heritage.org.uk/visit/ places/stonehenge/things-to-do/solstice/

Greaney, S., 2020. "Stonehenge Skyscape". Journal of Skyscape Archaeology 5 (2): 239-240. https://doi. org/10.1558/jsa.40034

Higginbottom, G. and R. Clay, 2015. "Connections: The Relationships between Neolithic and Bronze Age Megalithic Astronomy in Britain". In The Materiality of the Sky: Proceedings of the 22nd Annual SEAC Conference 2014, edited by F. Silva, T. Lomsdalen, K. Malville and F. Ventura, 177-188. Ceredigion: University of Wales, Trinity Sant David, Sofia Centre Press. 
Historic England 2020. "Training \& Skills Development Opportunities". [online] Accessed 8 July 2020. https:// historicengland.org.uk/services-skills/training-skills/

Natural History Museum 2020. "Quaternary Palaeoecology". [online] Accessed 8 July 2020. https://www. nhm.ac.uk/our-science/courses-and-students/short-course-quaternary-palaeoecology.html

Nowakowski, J. A., C. Kennett, J. Gossip and B. Sheen, 2020. "Investigating Archaeology and Astronomy at The Hurlers, Cornwall 2013-2019". Journal of Skyscape Archaeology 6 (1): 53-85. https://doi.org/10.1558/ jsa.39523

Ruggles, C., 2006. "Interpreting Solstitial Alignments in Late Neolithic Wessex". Archaeoastronomy: Supplement to Journal for the History of Astronomy 20: 1-27.

Stellarium v0.19.3-1 [online]. Accessed February 2020 https://stellarium.org

Thom, A., 1967. Megalithic Sites in Britain. Oxford: Clarendon Press.

University of Oxford, 2020. "Courses and Workshops in the Historic Environment" [online]. Accessed July 2020. https://www.conted.ox.ac.uk/about/historic-environment

University of Sheffield, 2020. "Zooarchaeology Short Courses" [online]. Accessed July 2020. https://www. sheffield.ac.uk/archaeology/short-courses/zooarchaeology 